\title{
GREEK PROPER NAMES IN ANCIENT LITERATURE TEXTBOOKS ON THE EXAMPLE OF BALTIC COUNTRIES ${ }^{1}$
}

\section{Л. Бодниеце, А. Кучинскиене, М.-К. Лотман. Греческие имена собственные в учебниках по классической филологии на примере стран Балтии.}

В статье рассматриваются процессы становления способов передачи (транслитерации) древнегреческих имен собственных в учебных пособиях на национальных языках в Латвии, Литве и Эстонии на протяжении последних ста лет, в том числе и влияние на эти процессы переводов с русского языка книг И. М. Тронского.

Ключевые слова: древнегреческий язык, имена собственные, классическая литература, «История античной литературы» И. М. Тронского.

\section{Introduction}

Although recently the importance of mapping and researching history of translation has been emphasized more and more, less attention has been paid to the need of doing it from the comparative perspective. Examining different traditions side by side makes it possible to notice significant features and regularities which would, perhaps, otherwise escape observation. Such an approach can also have practical advantages: it may help to provide a more precise and in-depth analysis of the translation norms and governing strategies. On the other hand, it can also have theoretical value from, for example, the points of view of the typology, evolutionary and conceptual studies, etc.

In addition to the most central questions such as «who translated?», «what was translated?», and «how it was translated?», the study of the history of translation has to take notice of narrower questions as well, including, for instance, renderings of puns, culture-specific items and terms, but also proper names. Proper

\footnotetext{
${ }^{1}$ The writing of this paper was supported by the Estonian Ministry of Education and Research, project no IUT20-1, and by the European Union through the European Regional Development Fund (Centre of Excellence in Estonian Studies). The research was supported by the Research Council of Lithuania (project: The Digital Data Basis of Ancient Proper Names, Principal Investigator: Audronė Kučinskienè).
} 
names are often more than just simply reflectors of orthographic norms: they can also be signs of an era, expressing the governing cultural and ideological trends, and these can be more distinctly brought out with the use of comparative analysis.

In translating proper names, broadly speaking, there are two opposite approaches: foreignizing and domesticating ways of translation $^{2}$. In the case of foreignizing translation, the name forms are presented as closely to the original as possible, while the domesticating translation attempts to change the name in a way that it would be familiar to the target culture, either by accommodating the name form to fit the target tradition or, for example, in the case of nomina loquentia (names with meaning) even replacing it with the target language equivalent (for instance, instead of Scipio Africanus, Scipio the African, or Hypnos as Sleep and Thanatos as Death). Yet even when the foreignizing method is chosen with the aim to render the names just like they are in the source culture, and in case of the chosen alphabet with the closest transcription possible, there is more nuances necessary to such an approach, as practice shows. For example, the stem of a name can be rendered following the original, but the morphological ending can be dropped or changed. On the other hand, variations can occur also in transcription rules and, as a result, the same name can be accurately transcribed but look entirely different.

The purpose of this paper is to compare the history of rendering Greek proper names in three countries with similar fate - Latvia, Lithuania and Estonia. In order to delimit the very broad material, we have chosen as our research subject literature study books, as one of the most professional and thought-out sources, on the one hand, but also because they are works which have considerable impact and serve as significant tools for popularizing the name forms.

\section{Greek names in ancient literature textbooks: the case of the Latvian language}

Rendering of ancient proper nouns in the Latvian language is an issue which becomes topical with every new publication within which such nouns are found. In this paper attention is paid to the

\footnotetext{
${ }^{2}$ For more distinct strategies see, for instance, Hermans 1988, where four main ways of translating proper names are presented, or Fernandes 2006, where as many as ten are listed.
} 
versions of renderings in the ancient literature text-books and anthologies.

In short, the history of ancient literature text-books in Latvian can be divided into two periods - before and after the occupation of Latvia. The translation into Latvian of Joseph Tronsky's book History of ancient literature (Antikās literaturas vēsture) marks the transition between these two periods, showing quite clearly the set course for not only the representation of ancient culture but also for the development of The Latvian language. It should also be noted that this is the largest publication in volume about the history of ancient literature in Latvian. Although, an anthology of ancient literature was published shortly after the restoration of Latvia's independence, there has since not been any new book of the history of ancient literature.

Before the inclusion of Latvia into the Soviet Union, two voluminous books of the history of ancient literature were published - K. Straubergs's Roman Literature (Romiešu literātūrai) in 1936 and P. Kiksauka's The History of Greek Literature (Grieksu literātüras vēsture) in 1944; that said, however, the first translations of ancient literature works in Latvian were made as early as mid-19th century (J. Alunāns, E. Veidenbaums, J. Rainis etc.). The era of the independent Latvia is also important for the popularization and research of ancient literature, because during this period the first philological translations of the ancient texts were made and several voluminous collections with translations and commentaries were published (K. Straubergs, Greek Lyrics (Grieksu lirika), 1922, Poetry by Horace (Horātija dzejas), 1924-1936, Homer's Odyssey translated by A. Giiezens (1943) etc.). Also during this time, countless translations and articles on ancient literature, culture and history were made.

Today this material gives theorists an insight into the early stages and development of the academic tradition of classical philology in Latvia. It offers a chance to trace the history of several ever topical questions, such as the issues of rendering ancient proper nouns, translations of ancient literary works' titles and terms of literary theory, linguistics and philosophy, and to learn which influences have come from Ancient Greek and Latin. The issues of the rendering of terms and proper nouns of Greek and Latin origin in the Latvian language became topical with the very first translations in the 19th century. In that rendering it is possible to see influences 
from intermediary languages, as well as versions, which resulted from the forming process of the Latvian literary language. Thus, at the start of the 20th century, several versions of rendering were used for one and the same word.

Inconsistency of the rendering of ancient proper nouns and terms has attracted the attention of linguists, which is demonstrated in a number of publications and polemics in scientific and popularscience issues (e.g. Garais 1930; Plāķis 1926; Felsbergs 1922, etc.).

As both of the books about the history of literature published in the period of independence show, their authors had concluded that in the rendering of Greek and Latin words (in this case it can also be applied to terms) one should as much as possible seek conformity with their classical pronunciations. However, the choice of this approach has not given strictly defined, unambiguous principles of rendering, especially, in the case of Greek words. There are issues which are argued about even now, for example, whether the stress in Greek should be rendered in Latvian as a long vowel, how to render the rough breathing and aspirated consonants, etc. Furthermore, alongside the academically guided discussion of the issue, there are versions which are created by the translators and renders in poetry form and come into everyday use.

The rich choice of materials, which were made until 1944, demonstrate that the start of the century had been a period in which different Ancient Greek and Latin word rendering principles were defined, as several rendering versions were being created at the same time.

The situation changed with the political landscape. Similarly to other areas of life, the new approach to language tried to eradicate diversity of thought and approaches in sciences. This can be seen particularly in the books, which were published at the start of the 50s, - in Anthology of Ancient Literature (Antīkās literatūras antologijas, 1951 and 1952), translation of Joseph Tronsky's History of Ancient Literature (1954) and Latin-Latvian dictionary (1955), the most voluminous source of renderings of Latin proper nouns in Latvian. Furthermore, the principles of proper noun rendering were subjected to the influence of Russian language: long vowels were not used in the rendering of proper nouns and terms (Homers, Horacijs, etc.). 


\begin{tabular}{|c|c|c|}
\hline Greek/Latin & P.Ķik̦auka 1944 & I.Tronskis 1954 \\
\hline Aivéas / Aenēās & Ainejs & Enejs \\
\hline A $\chi \imath \lambda \lambda \varepsilon v ́ \varsigma$ Achilleus & Achillejs & Achiless \\
\hline Aī $\chi \dot{\lambda} \lambda \mathrm{oc} /$ Aeschylus & Aischils & Eschils \\
\hline Aíā / Aiāx & Aiants & Ajakss (Ajants) \\
\hline 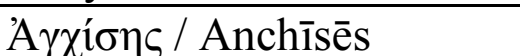 & Anchīss & Anchizs \\
\hline Eủpī $\pi$ í́ns / Eurīpidēs & Eurīpids & Eiripids \\
\hline  & Isokrats & Izokrats \\
\hline 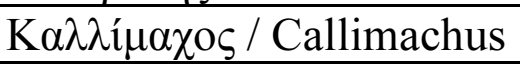 & Kallimachs & Kalimachs \\
\hline$\Lambda \bar{v} \sigma i \bar{\alpha} \varsigma /$ Lȳsiās & Līsijs & Lizijs \\
\hline  & Odisejs & Odisejs \\
\hline Oíoínovs / Oedipūs & Oidips & Edips \\
\hline 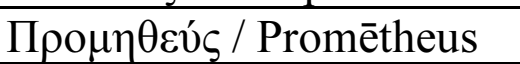 & Promētejs & Prometejs \\
\hline$\Sigma \alpha \pi \varphi \omega ́$ / Sapphō & Sapfoja & Sapfo \\
\hline 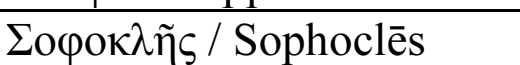 & Sofokls & Sofokls \\
\hline 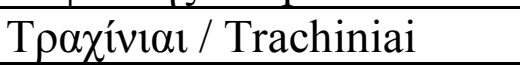 & Trāchīnietes & Trachinietes \\
\hline
\end{tabular}

In the appendixes of Joseph Tronsky's History of Ancient Literature, indexes can be found which contain renderings of literature terms, proper nouns and titles. Most of them differ from those used in the previous books; as well, all of the titles of ancient literary works are translated into Latvian. Perhaps, this is because in the original book titles of the ancient works', the translations are given in Russian. This seems unsuitable in Latvian translation as most of the mentioned works have not been translated into Latvian. Separate works, which are translated into Latvian, had been published before the Soviet times and in these issues writing of the titles and rendering of author names differ considerably from the ones used in Tronsky's book. Similar solution can be found for the translations of the literary works quoted in this book, - perhaps, fragments from the existing translations were used but a great deal of the translations were made especially for this issue. The book does not contain translations of the classical philologists, who emigrated from the country; instead, in the bibliography only translations into Russian are shown.

It seems that these kinds of voluminous materials (history of literature, anthologies and dictionary) were published because the new power tried to set the course of the approach to language and the direction of the interpretation of cultural heritage. Even though the new ideas were shown through the previously mentioned issues, 
which served throughout the Soviet times as the most important reading sources in Latvian about ancient literature and Latin language, they did not establish rendering principles of proper nouns. Macrons in the proper nouns had already returned, although not everywhere and not consistently, in 1959 with the translation from Russian language of N. Kun's Ancient Greek Myths and Heroics (Sengrieķu mīti un varoņteikas).

Later publications, such as L. Čerfase's and T. Fomina's History of Ancient Literature (1986) start a new peculiar «tradition» republishing of already published translations, while changing the renderings of proper nouns and words of ancient languages' origins. This book of the history of literature structurally, and in content, follows the example of Tronsky's book. Several statements and examples have been taken straight out of it, but the rendering of proper nouns has been changed.

After the reestablishment of the independence of Latvia a new anthology of ancient literature was published in two books. The structure of the anthology is similar to the ones published in the 1950s; however, it shows the newest approaches in the rendering of proper nouns. Moreover, it continues the tradition of arbitrary correction of the writing of proper nouns and foreign words, republishing previously published translations of ancient literature. It should be noted that N. Kun's Ancient Greek Myths and Heroics gets a new issue in 2016 and in it the translation of 1959 is revised according to the standards of today's Latvian language and, of course, the rendering of proper nouns also has been altered.

The issue of rendering Greek and Latin origin proper nouns is ever topical and present in the arena of Latvian humanities. After the restoration of the independence, when classical philology was revived in Latvia, there have been several publications on this topic.

Insight into the rendering of proper nouns from books on the history of the ancient literature in the Latvian language confirm the thesis that there are no unambiguous and unchangeable solutions for this issue. Volumes of ancient literature from every century try to represent a scientifically reasoned, regulated and unified approach to it, but as soon as there are new materials made these approaches have already lost their topicality.

Even though the historical texts on the ancient literature should serve as the most reliable source for rendering of ancient proper nouns, it is not always so. N. Kun's translation of retellings of 
myths, which was published soon after the translation of Tronsky's book, is a good example of that.

Today the previous materials cannot be ignored within scientific publications and resources about ancient authors and literature, as those texts are the only accessible materials in Latvian which can be included into bibliography. The renderings of terms and proper nouns, which are found in the appendixes of Joseph Tronsky's book, are without long vowels, so they are not used in modern Latvian language, but the content of the book has not lost its significance.

It is highly unlikely that a new history of ancient Latvian literature will be published in the nearest future. Right now, however, under the wing of National Library of Latvia, a new National encyclopaedia honouring the centenary of Latvia is being made with the plan to also contain entries on the ancient world. So, the writers of these entries have new challenges: What should be done with the rendering of the ancient proper nouns? How to render the terms of ancient literature? And, how to create and comment on the bibliography, which is accessible in Latvian?

\section{Joseph Tronsky's «History of Ancient literature» in Lithuanian: between two traditions}

The problem of Lithuanization of ancient names was and still is relevant, and not fully resolved. It is manifested by variation in spelling of names as well as by ongoing discussions and considerations on properly reconciling language and history in the media.

The history of Ancient Greek and Latin proper names in Lithuanian can be traced to the earliest scripts of 16th century, although some biblical names had come into spoken the Lithuanian language even earlier, with baptism in Lithuania, in 14th century. Nevertheless, we can easily conclude that from the 16-18th century usage and transcription of ancient names in Lithuanian were sporadic, without any rules or system. Sometimes the words are used as would be the spoken vulgar language, i.e. adapted to the rules of Lithuanian dialects. In other cases, however, they are influenced by Polish, or simply written in original Latin form with Lithuanian ending. The only clear tendency observed from the first Lithuanian writings and, in essence, maintained in modern use is writing Latin nouns according to the rules of medieval 
pronunciation. In Lithuania, this was the case due to activity of the Catholic Church and other cultural institutions (Vilnius University in 16-18th c., etc.).

The first deliberate attempts to introduce some order in the writing of ancient nouns in Lithuanian showed at the end of the 19th and especially the beginning of 20th century. It was a time when Lithuanian nationalist movement led to the State's first independence, when Lithuanian press ban was ended (in 1904), and cultural identity in all its forms became more vigorous. In this period of the first state independence, before the Second World War, Kaunas University was established and continued the academic tradition of classical studies in Lithuania. It was an active period when textbooks for schools and university students were written or translated, and monographic studies in Greek literature and art history were written by professors of Kaunas University. In the press, discussions and book reviews identified the problem of writing ancient names in Lithuanian and both sides were very actively discussed and argued. In 1920s and 1930s the first fundamental translations made both by classical scholars and nonprofessionals who had an excellent command of ancient languages from classical gymnasium education came into acceptance. Among the most prominent were the translations of Homer's poems ${ }^{3}$, several Plato's dialogues, Ancient Greek tragedies and comedies, as well as numerous excerpts from various Latin authors, such as Ovid, Virgil, Horace, Tibullus, Cicero, Caesar etc. can be mentioned ${ }^{4}$. Studies of ancient literature (V. Dubas, Introduction to General Literature (Ivadas i bendraja literatūra), Kaunas, 1923; Vladimiras Šilkarskis, Homer and Greek Epic Poetry (Homeras ir graiku epine poezija), Kaunas, 1937; Vladimiras Šilkarskis, The History of Greek Literature (Graiku literatūros istorija. Pirmas tomas: Klasikinis laikotarpis, Kaunas,1938) as well as anthologies (Visuotines literatūros chrestomatija. I-ji dalis: Graikai ir Roménai, sudarė J.

\footnotetext{
${ }^{3}$ The most important were the translations of Homer's Odyssey and Iliad by Jeronimas Ralys. Odyssey was translated by Jeronimas Ralys and first published in 1921. The second edition, revised by Vladimiras Silkarskis, followed in 1937. Iliad, translated by J. Ralys and others, and revised by was Vladimiras Šilkarskis, was published in 1930.

${ }^{4}$ Detailed bibliography of the translations from ancient Greek and Latin into Lithianian can be found in the Digital data base Index Lituanicus: www.indexlituanicus.flf.vu.lt/.
} 
Talmantas, Kaunas, 1930), textbooks (Parinktos Kvinto Horaciaus Flakko giesmès (odès) su komentarais ir žodžiais, paruošè K. Kepalas, Kaunas, 1928), Latin-Lithuanian dictionary (Kazimieras Jokantas, Lotyniškai lietuviškas žodynas, Kaunas, 1936) were also important for rendering of ancient names into The Lithuanian language.

We can claim rather firmly that some more or less established tendencies of Lithuanization of Greek names following the original form can be observed during this period. These principles were worked out and used in practice by professors of the classics of Kaunas University including Franz Brender, Vladimiras Šilkarskis together with professors of the Lithuanian language Pranas Skardžius, Antanas Salys. We can suppose that it would have become an established tradition, if it had been further developed. These are the main principles of Lithuanization the Greek names:

1. Greek nouns of the 3rd declination are transcribed into Lithuanian on the root of genitivus: Artemida ('A $\rho \tau \varepsilon \mu 1 \varsigma, \breve{\imath} \delta o \varsigma \dot{\eta}$ ),



2. All Greek diphthongs are transcribed as Lithuanian correspon-

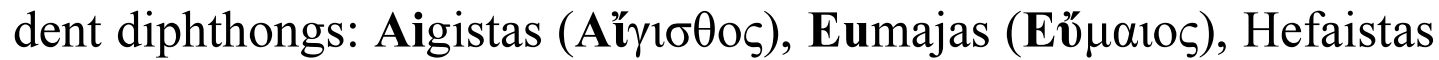

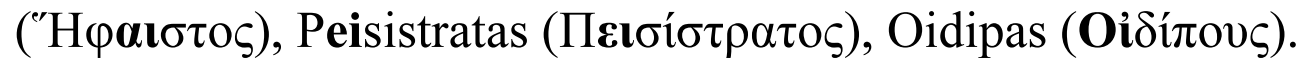

3. Greek sigma between two vowels is transcribed as Lithuanian

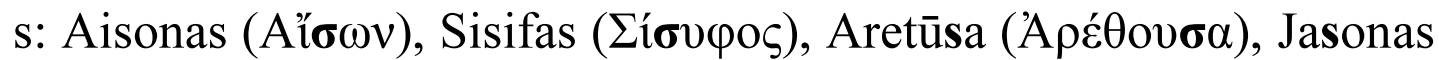
('Ió $\sigma \omega v)$.

4. Greek dzeta is transcribed as dz: Dzeusas (Zqúc), Dzakintas

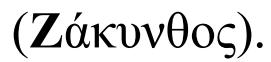

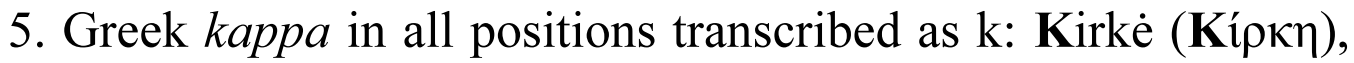

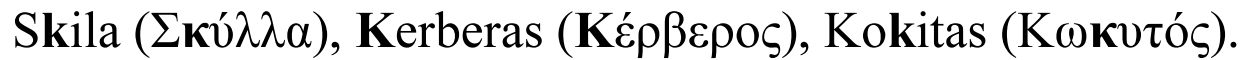

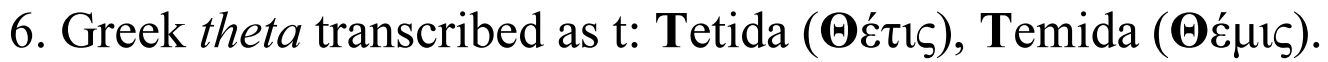

7. Greek geminates ar transcribed as doble consonants:



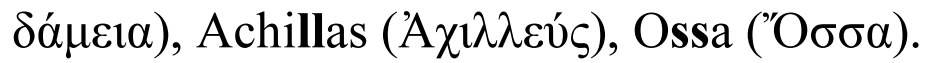

The situation changes after the Second World War. Some professors and translators emigrated to the West, while others were banished to Soviet prison camps. Those who remained moved to Vilnius together with the Department of Classical Philology, after Vilnius University was reopened in 1940.

It is extremely interesting to observe how and when the influence of Soviet unification, politics and of the Russian language, started operating in the usage of the ancient names in Lithuanian. On 
the one hand, the tendencies of rendering Ancient Greek names, mentioned above, continue well into the second and third decade of the Soviet occupation, especially in translations of ancient authors ${ }^{5}$. On the other hand, new translations from Russian, such as textbooks on ancient history Senoves istorija, red. A. V. Mišulinas (1946); V. Sergejevas, Senovès Graikijos istorija (1952), were influenced greatly by Russian and digressed from earlier principles of rendering Ancient Greek proper names.

The crucial break with the previously followed tendencies can be observed in the Joseph Tronsky's History of ancient literature, translated from Russian and published several times (Tronski 1951; 1955, 1961). This was the main textbook of Greek and Latin literature for university students until the new textbook Ancient literature (Antikine literatūra) by Dalia Dilyte replaced it in 1998 (Dilyte 1998). A comparison of the two editions of 1951 and 1961 shows rather clearly the changes in main principles:

1. Greek diphthongs $\alpha$ and or are transcribed as Lithuanian diphthongs $a i, o i$ in the first edition, and as a vowel $e$, peculiar to Russian, in the second.

\begin{tabular}{|c|c|c|}
\hline & Tronsky 1951 & Tronsky 1961 \\
\hline 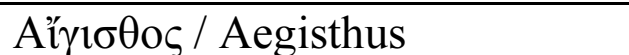 & Aigistas & Egistas \\
\hline Aioxívnc/ Aeschinēs & Aischinas & Eschinas \\
\hline 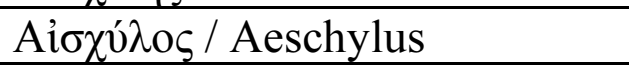 & Aischilas & Eschilas \\
\hline 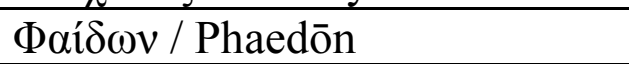 & Faidonas & Fedonas \\
\hline 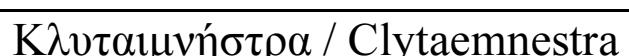 & Klitaimnestra & Klitemnestra \\
\hline 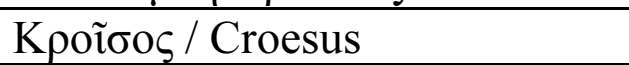 & Kroisas & Krezas \\
\hline Oídítovs / Oedipūs & Oidipas & Edipas \\
\hline Фoĩßos / Phoebus & Foibas & Febas \\
\hline
\end{tabular}

2. The geminate consonants disappear both from Latin and Greek proper names in Lithuanian rendering:

\begin{tabular}{|l|l|l|}
\hline & Tronsky 1951 & Tronsky 1961 \\
\hline Atta & Atta & Ata \\
\hline 'A $\tau \alpha \lambda$ o $\varsigma /$ Attalus & Attalas & Atalas \\
\hline Cinna & Cinna & Cina \\
\hline
\end{tabular}

${ }^{5}$ For instance, Aeschylus' Prometheus Bound (Aischilas, Prikaltasis Prometèjas, vertė R. Mironas, Vilnius: Valstybinè grožinès literatūros leidykla, 1947); new edition of Homer's Odyssey, translated by J. Ralys (1948) follows its earlier version (1937), rendered by prof. Vladimiras Silkarskis. 


\begin{tabular}{|l|l|l|}
\hline Catullus & Katullas & Katulas \\
\hline Kópıvva / Corinna & Korinna & Korina \\
\hline Ennius & Ennijus & Enijus \\
\hline Gallus & Gallas & Galas \\
\hline Gellius & Gellijus & Gelijus \\
\hline
\end{tabular}

3. In the position between two vowels $j$ is written to make clear division between two syllables in the first Tronky's edition, and it disappears in the second.

\begin{tabular}{|c|c|c|}
\hline & Tronsky 1951 & Tronsky 1961 \\
\hline Fabiānus & Fabijanas & Fabianas \\
\hline 'I $\lambda_{1 \alpha ́}$ S / Ilias & Ilijada & Iliada \\
\hline ’I & Ilijonas & Ilionas \\
\hline 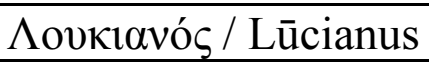 & Lukijanas & Lukianas \\
\hline Apí $\omega v$ / Arīōn & Arijonas & Arionas \\
\hline
\end{tabular}

4. In several cases Greek sigma between two vowels is transcribed as Lithuanian $z$ by the influence of the Medieval pronunciation of Latin. This becomes even more established tendency throughout the Soviet period.

\begin{tabular}{|c|c|c|}
\hline & Tronsky 1951 & Tronsky 1961 \\
\hline Bpī̄ołíç / Brīsēis & Brizejidè & Brizeidè \\
\hline 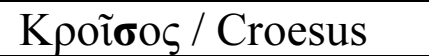 & Kroisas & Krezas \\
\hline 'Hoíodos / Hēsiodus & Heziodas & Heziodas \\
\hline$\Delta$ tóvō̄os/ Dionȳsus & Dionizas & Dionizas \\
\hline Kроїбоక / Croesus & Kroisas & Krezas \\
\hline
\end{tabular}

We could not affirm, that the translation of Tronsky's textbook had a significant influence on the rendering Ancient Greek and Latin names in Lithuanian. Rather to the contrary, the tendency to follow Russian as an example was forced upon the authors of this translation. Disagreements with the editors of the second edition made one of translators, Jonas Dumčius, start his fundamental research on the problem. As a result a voluminous thesis entitled Ancient Proper Names in the Lithuanian Language (VU, 1958) was written which comprises two volumes, totalling about 900 pages. Dumčius' study covers the history of biblical and Ancient Greek, and Latin proper names in Lithuanian starting with the very first Lithuanian scripts of 16th century and going to the 1950s (Dumčius, 1958). 
After the restoration of the independence in Lithuania, some principles of the Lithuanization of Greek names following the original form, which prevailed before Soviet period, were more or less reestablished, for instance the transcription of Greek diphthongs as Lithuanian ai and oi. At the same time, the rendering of Latin names according to the medieval tradition remained unchanged. The problem usually occurred in those books or anthologies were both Greek and Latin proper names are included. The same name was written differently in accordance to its Latin or Greek context, for instance Faidra, Aigistas in Euripides' plays, and at the same time Fedra, Egistas in Seneca's.

A Digital Data Base of Ancient Proper Names was created in $2015^{6}$. Pooling proper nouns, both in Greek and Latin (totally about 12 thousands), in a single database, provides a more general view and allows establishing the criteria for Lithuanization of names as well as formulating general principles and specific rules, i.e. enables attempts to develop a theoretical Lithuanian transcription system. But a perfect system is hardly possible - each rule has exceptions, taking into account the established spelling of individual nouns. The main principle of the database is to maintain the phonetic and morphologic parameters of Greek and Latin nouns as close to the original as possible by harmonising them with the patterns of the Lithuanian language, and with regard to the prevalence of those Greek and Latin nouns in Modern Lithuanian.

\section{Greek names in Estonian literature study books}

Rendering ancient names in Estonia is not a unique; there are quite important features in common with those found with the other Baltic states. In the 19th century and at the beginning of 20th century, various forms of proper names were used completely unsystematically. Sometimes German name forms were applied, while at other times different principles of transcription; especially remarkable is the difference in the orthography of the words containing Greek consonants $\chi, \theta, \varphi$ and $\xi$ and vowel $v$. There is also confusion in the name endings: sometimes Greek -os was used,

\footnotetext{
${ }^{6}$ The project «Digital Data Base of Ancient Proper Names» was founded by Research Council of Lithuania, 2013 June - 2015 July, and was finished by the group of scholars of Vilnius University. The data base is freely acceptable to all users: http://www.vardynas.flf.vu.lt/
} 
sometimes latinized -us, while sometimes the ending was dropped entirely. There are also inconsistencies in rendering the vowel lengths: occasionally the long vowel was transcribed with the double vowel in Estonian, while on other occasions the length was not reflected at all in the name form. However, what was rare especially in comparison with other Baltic languages - was the derivation of the name form from the genitive stem: usually the name was rendered from the nominative of the original.

However, in 1920s certain tendencies towards formation of rules can be noted, forming rules which at the time were also being popularized within literature study books. During that first period of independence, quite a few of these were published in texts: in 1926 appeared the first part of "Ancient Greek literature» by Tadeusz Zieliński, in the next year the second part as well. In rendering the Greek proper names the translator Linda Metslang adopted the following rules:

1. Greek proper names are transcribed to Estonian on the root of

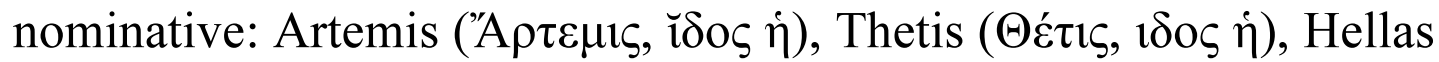

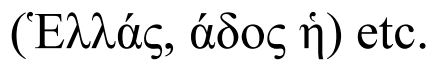

2. All Greek diphthongs are transcribed as Estonian correspon-

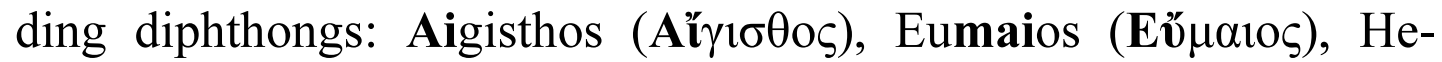

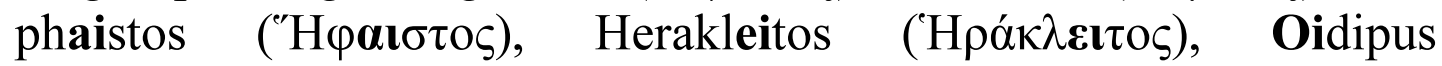

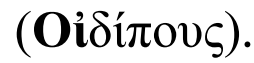

3. Greek $\zeta$ is transcribed using the foreign letter z: Zeus (Zqú $\zeta)$.

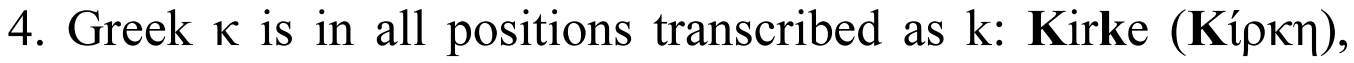
Skylla $(\Sigma \kappa v ́ \lambda \lambda \alpha)$, Kreon $(K \rho \varepsilon ́ \omega v)$.

5. Greek $\varphi$ is transcribed as ph: Sappho ( $\Sigma \alpha \pi \varphi \omega ́)$, Phaidra

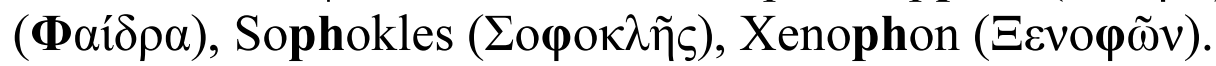

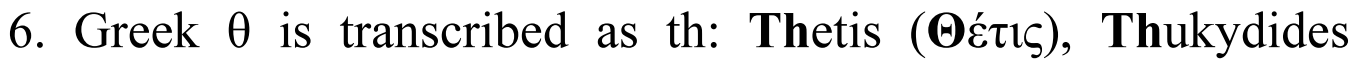

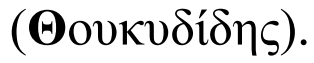

7. Greek $\chi$ is transcribed as ch: Aischylos (Aiَ $\chi \hat{\nu} \lambda \circ \varsigma$ ), Achilleus

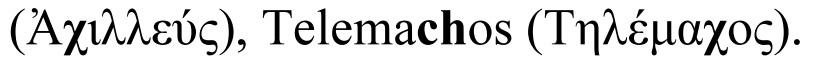

8. Greek geminates are transcribed as double consonants:

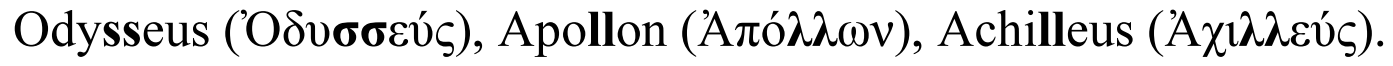

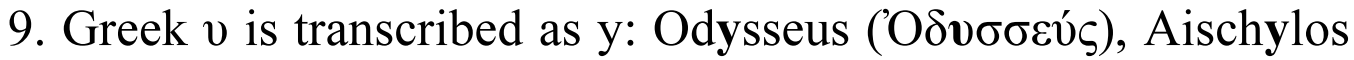

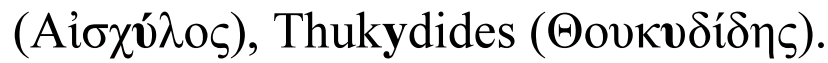

On the other hand, different approaches can be clearly seen with the rendering of proper names and toponyms: in toponyms, $\theta$ and $\varphi$ are simplified to estonianized non-aspirated consonants (Teeba, Efesos), while instead of $y$, an Estonian vowel $\ddot{u}$ is used: Küreene, 
Siküoon. A double consonant is used only for the Greek $\chi$ : Achaia

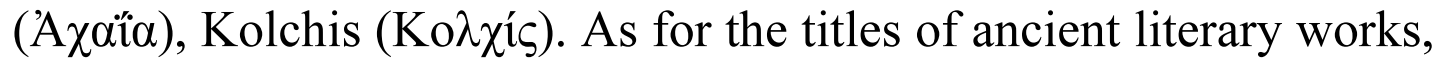
we see certain inconsistencies: in some places these are transcribed following the rules of proper names, in other places these are simplified like toponyms. Still, Metslang's principles created a standard: the same rules were followed by Ervin Roos, who published his Overview of ancient Greek literature in 1935; the differences are revealed mostly in some titles, which were rendered with different rules than the proper names but were simplified in accordance with the simplifying principles of rendering the proper names, thus, «Odysseia» became «Odüsseia» and «Trachiniai» became «Trahhiinlannad». Still, some titles were foreignizing, like, for example, «Eirene» and «Thesmophoriazusai» by Aristophanes (Metslang's version is more simplified «Tesmoforiad»).

Quite soon after Estonia was occupied, already in 1949, Joseph Tronsky's History of Ancient Literature (Antiikkirjanduse ajalugu, translated by Aita Kurfeldt) was published in Estonian. In comparison with the prior republic's standards, certain changes can be seen in her transcription, which, first of all, concern the transcription of $\varphi$ and $v$ - the first is rendered in proper names as $f$, the second as ü: Sapfo and Odüsseus. Since $\theta$ and $\chi$ are rendered in accordance with earlier principles, we can see a certain inconsistency here. Compare the orthography of proper names in the study books by Zieliński and Tronsky:

\begin{tabular}{|c|c|c|}
\hline Greek/Latin & Zieliński 1926 & Tronsky 1949 \\
\hline A $\chi 1 \lambda \lambda \varepsilon v ́ \varsigma$ Achilleus & Achilleus & Achilleus \\
\hline 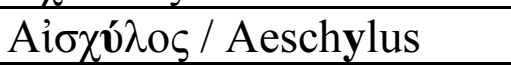 & Aischylos & Aischülos \\
\hline Atúa $/$ / Aiāx & Aias & Aias \\
\hline Eủpī $\pi$ íons / Eurīpidēs & Euripides & Euripides \\
\hline 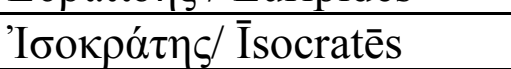 & Isokrates & Isokrates \\
\hline 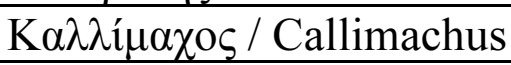 & Kallimachos & Kallimachos \\
\hline$\Lambda \bar{v} \sigma^{\prime} \hat{\alpha} \varsigma_{\varsigma} /$ Lȳsiās & Lysias & Lüsias \\
\hline 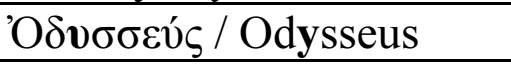 & Odysseus & Odüsseus \\
\hline 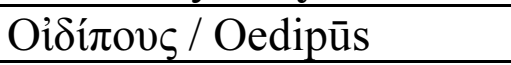 & Oidipus & Oidipus \\
\hline Про $\mu \eta \theta \varepsilon v ́ \varsigma /$ Promētheus & Prometheus & Prometheus \\
\hline$\sum \alpha \pi \varphi \hat{\omega}$ / Sapphō & Sappho & Sapfo \\
\hline 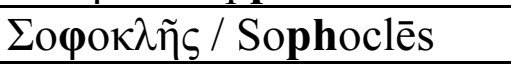 & Sophokles & Sofokles \\
\hline
\end{tabular}


The next table exemplifies the rendering of titles.

\begin{tabular}{|c|c|c|}
\hline Greek & Zieliński 1926 & Tronsky 1949 \\
\hline 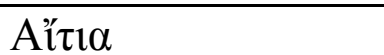 & Aitia & Põhjused \\
\hline A $\chi \alpha \rho \nu \varepsilon \tilde{i} \varsigma$ & Acharnalased & Ahharnlased \\
\hline Bákqal & Bakchid & Bakhandid \\
\hline Eīńvn & Eirene & Rahu \\
\hline 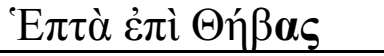 & Seitse Teeba vastu & Seitse Teebai vastu \\
\hline${ }^{\circ} H \rho \alpha \kappa \lambda \varepsilon i \tilde{\delta} \alpha \iota$ & Herakleidai & Herakleidid \\
\hline$\Theta \varepsilon \sigma \mu о \varphi о \rho і \alpha ́ \zeta o v \sigma \alpha \imath$ & Tesmoforiad & Naised tesmofooride pühal \\
\hline 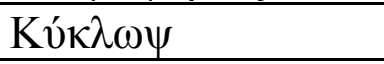 & Küklops & Kükloop \\
\hline 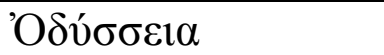 & Odysseia & Odüsseia \\
\hline 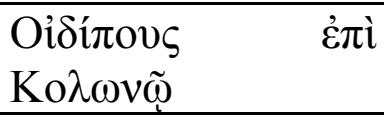 & Oidipus Koloonoses & Oidipus Koloonoses \\
\hline 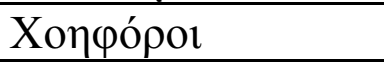 & Choefoorid & Choeforoi \\
\hline 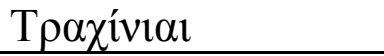 & Trachiniai & Trahhiinlannad \\
\hline
\end{tabular}

Here we can see even more confusion than in the case of proper names: occasionally, there is a domesticating approach («Trahhiinlannad»), in other places the titles are translated to Estonian («Põhjused», «Rahu»), and sometimes we can see a foreignizing approach («Choephoroi»). There are also inconsistencies in transcribing Greek words (cf «Ahharnlased» vs «Choeforoi»).

Soon after Tronsky's book was published, together with the compilation of Big Estonian ortographic dictionary, the problem of the orthography of ancient proper names resurfaced. The department of dictionaries and orthography in the Institute of the Estonian Language and Literature was engaged in this task and Ernst Nurm, a linguist and lexicologist, has to be recognized for his contribution: he developed specific instructions for rendering ancient names. These evoked ardent response and at the end of 1950s started heated discussions over the Estonification of proper names. There were two opposing sides, one of which was represented by Ernst Nurm, the other by Ain Kaalep, a young linguist at that time, later a distinguished poet and critic, and Johannes Veski, who was the head of the department of dictionaries and orthography, and also an esteemed linguist and a composer of dictionaries of the Estonian language. In 1958, Ernst Nurm published a paper where he mainly discussed how Greek names in Estonian have to be delatinized, that is, $\xi$ has to be consistently rendered not as $x$, but as $k s$, $\varphi$ not as $p h$, but as $f, \chi$ not as $c h$, but as $h h, \theta$ not as $t h$, but as $t, \dot{\rho}$ not as $r h$, but as 
$r$, and $v$ not as $y$, but as $\ddot{u}$. Evidently, his intention was to introduce the principles, earlier used for toponyms, also for rendering proper names, thus taking up and generalizing Kurfeldt's method of transcribing $\varphi$ and $v$ in her Tronsky's translation.

Kaalep and Veski, however, fought against this approach, both in special discussion meetings and in their academic papers. Veski (1961) criticized Nurm for the lack of consistency ( $\xi$ is only sporadically transcribed as ' $\mathrm{ks}$ '), and also presented a number of linguistic arguments why he does not consider Nurm's approach suitable. Kaalep (1961) rebuked Nurm for creating confusion, but also brought a number of pragmatic and linguistic arguments why the latinized name forms should be preferred.

After these events we can see that the two different systems of transcriptions are used simultaneously for a period of time. The translations of the Iliad (1960) and the Odyssey (1963) popularized the republic's standards of proper names; however, when we take a look at newspaper articles, we see that the name forms proposed by Nurm are repeatedly used. In 1966, the State Orthography Committee discussed among other topics the problem of transcribing Greek proper names, but neither of the proposed systems achieved the necessary majority of votes to make a favouring ruling (Raiet 1966: 178).

Yet, the standards which were developed during the first period of the independence became prevailingly dominant, happening primarily through the prolific publishing of the supporters of this system. Here, for its early leadership, the project of Estonian Soviet Encyclopedia has to be mentioned: where the section of the articles about literature was supervised by Ain Kaalep and classicist Richard Kleis, who also favoured the latinized forms. Secondly, the anthologies of ancient literature (in 1964 the anthology of Greek literature and in 1971 the anthology of Roman literature) are certainly of relevance. And third, perhaps even the most important are the study materials composed by Richard Kleis, which widely popularized these standards at the higher educational level starting in 1964 with the first original Greek literature study book after Estonia was occupied. The orthography of proper names does not follow Nurms's suggestions here and when we compare again the orthography of the same names, we can conclude that Kleis returned completely to the republic's orthographic rules: 


\begin{tabular}{|c|c|c|}
\hline Greek/Latin & Zieliński 1926 & Kleis 1964 \\
\hline A $\chi \imath \lambda \lambda \varepsilon v ́ \varsigma$ Achilleus & Achilleus & Achilleus \\
\hline 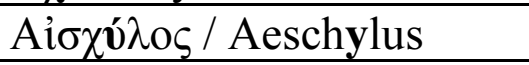 & Aischylos & Aischylos \\
\hline Aî̄̄ / Aiāx & Aias & Aias \\
\hline 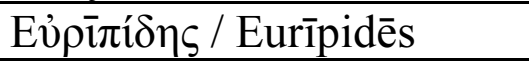 & Euripides & Euripides \\
\hline 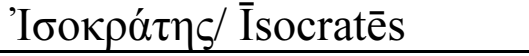 & Isokrates & Isokrates \\
\hline 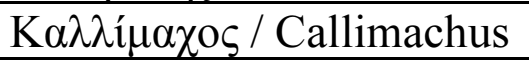 & Kallimachos & Kallimachos \\
\hline 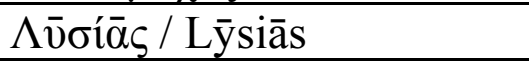 & Lysias & Lysias \\
\hline 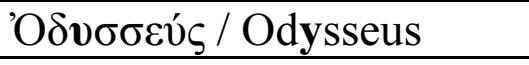 & Odysseus & Odysseus \\
\hline 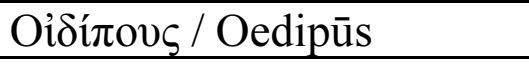 & Oidipus & Oidipus \\
\hline 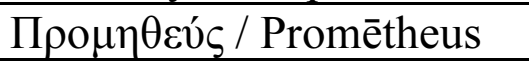 & Prometheus & Prometheus \\
\hline$\sum \alpha \pi \varphi \omega ́$ / Sapphō & Sappho & Sappho \\
\hline 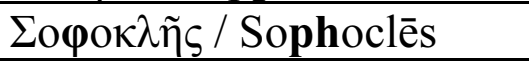 & Sophokles & Sophokles \\
\hline
\end{tabular}

However, some significant changes can be seen in renderings of the titles:

\begin{tabular}{|c|c|c|}
\hline Kreeka & Zieliński 1926 & Kleis 1964 \\
\hline Aïtıа & Aitia & Põhjused \\
\hline 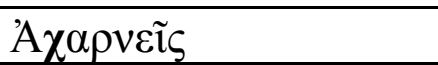 & Acharnalased & Ahharnlased \\
\hline 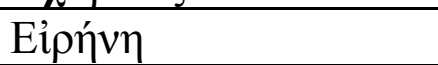 & Eirene & Rahu \\
\hline${ }^{E} \mathrm{\pi} \tau \grave{\alpha}$ غ̇ं $\pi \grave{\imath} \Theta \dot{\beta} \boldsymbol{\alpha} \varsigma$ & Seitse Teeba vastu & Seitse Teeba vastu \\
\hline 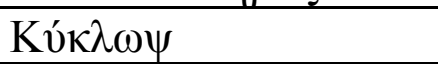 & Küklops & Kükloop \\
\hline 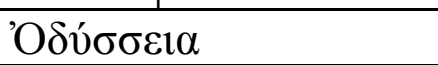 & Odysseia & Odüsseia \\
\hline 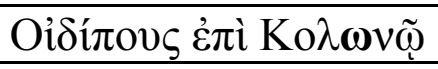 & Oidipus Koloonoses & Oidipus Kolonoses \\
\hline 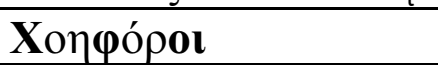 & Choefoorid & Hoefoorid \\
\hline 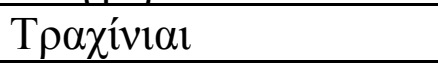 & Trachiniai & Trahhislannad \\
\hline
\end{tabular}

Here Kleis followed the domesticating principles, which were taken up already by Aita Kurfeldt, but he executed them systematically and consistently, thus, «Choephoroi» became «Hoefoorid», «Trahhiinlannad» is rendered more accurately as «Trahhislannad». At the same time, the inconsistent attempts of the earlier authors to render Greek long vowels with Estonian double vowels are given up: for instance, the toponym for Troy (Trooja) follows the established tradition, while the Sophoclean tragedy «Oedipus at Colonus» is rendered consistently with short Estonian vowels «Oidipus Kolonoses».

The following are a summary of Kleis's principles: in proper names the latinized transcription is used, applying foreign letters $x$, $y, c$ and $z$ if necessary, but the morphological endings in the nominative form are still Greek (for instance, -os and -on); and, in 
titles the Estonified forms are used. In 1980, Kleis published the study book on ancient literature and here the same principles are applied.

Such an orthography of proper names has been in effect up till now, although we sometimes see a certain tendency to name forms like «Odysseia», in which case the title has been influenced by the form of the proper name Odysseus. Yet currently the Press of the University of Tartu is preparing a publication of the collection Literature in the Greek and Roman Worlds (edited by Oliver Taplin), and there all the forms of ancient proper names follow the rules popularized by Ain Kaalep and Richard Kleis.

The classicists of the University of Tartu are currently preparing an online data base of ancient proper names (base funding project of the University of Tartu No. PHVLC16933, head of the project: Kadri Novikov). The purpose of the dictionary is to present the recommended renderings of ancient proper and geographical names to Estonian, adding also the parallel forms in different dictionaries and translations with the aim to serve as a tool for translators, editors, students, as well as the researchers of language and translation.

\section{Summary}

The history of orthography of ancient proper names in the three Baltic states reveals similar evolutionary patterns:

1) the period of diversity, when different renderings of proper names are used unsystematically;

2) first attempts of standardization and the beginning of establishing the norms;

3) the Soviet period, when the republic's standards are questioned and disputes over them were at least partially brought about by the publishing of Tronsky's book. As a result, several different systems can be used in parallel;

4) the period after the independence was gained and the standards of rendering the ancient proper names were again revised, by either reviving the old ones or creating the new ones

The standardization is not yet complete in any of the three Baltic states. Even if some of the general standards have been formulated, there is still a number of issues which are yet to be solved, like, for example, Greek names in Latin context, the titles of ancient works, place names and dilemmas between accuracy and tradition. 


\section{References}

Antikās literatūras antologiija I. Rīga: Latvijas Valsts izdevniecība, 1951. Antikās literatūras antologija II. Rīga: Latvijas Valsts izdevniecība, 1952. Aischylos $1947=$ Aischilas. Prikaltasis Prometejjas. Tlk Ričardas Mironas. Vilnius: Valstybinè grožinès literatūros leidykla.

Čerfasa, L., Fomina, T. 1968: Antīkās literatūras vēsture. Rīga: Zvaigzne.

Dilytė, D. 1998: Antikine literatūra. Vilnius: Jošara (kordustrükid: 1999, Vilnius: Jandrija, 2005, Vilniaus universiteto leidykla). Дилите, Д. 2003: Античная литература. пер. с литовского Н. К. Малинаускене. М.: Греко-лат. кабинет Ю. А. Шичалина.

Dumčius, J. 1958: Antičnyje imena sobstvennyje v litovskom jazyke. Vilnius [käsikiri].

Felsbergs, E. 1922: Grieķu īpašvārdu pareizrakstība latviešu valodā. Rīga: Latvijas Universitātes izdevums.

Fernandes, L. 2006: Translation of names in children s fantasy literature: Bringing young reader into play. https://www.researchgate.net/ publication/237246131

Garais, F. 1930 : Daži latviešu valodas jautājumi. Rīga: Autora izdevums.

Hermans, Th. 1988: On Translating Proper Names, with reference to De Witte and Max Havelaar. In: Wintle, M. J. (toim.). Modern Dutch Studies. Essays in Honour of Prof.r P. King on the Occasion of his Retirement. London; Atlantic Highlands: The Athlone Press, 11-24.

Homeros 1937 = Homeras. Odiseja. Tlk Vladimiras Šilkarskis. Kaunas: Švietimo ministerijos KLK-jos leidinys.

Homeros $1948=$ Homeras. Odisejja. Tlk Jeronimas Ralys. Vilnius: Valstybinè grožinès literatūros leidykla.

Homeros 1943 = Homērs. Odiseja. Tlk Augusts Ģiezens. Rīga: Latviju grāmata.

Horatius 1924-1936 = Horatius. Horātija dzejas. Tlk Kārlis Straubergs. Rīga: A.Gulbis.

Kaalep, A. 1961: «Keele ja Kirjanduse» ringküsitlusest. Keel ja Kirjandus, nr 1, nr 2, lk 41-46, lk 109-115.

Kiksauka, P. 1944: Grieķu literātūras vēsture. Rīga: Universitātes apgāds.

Kleis, R. 1964: Vana-Kreeka kirjanduse põhijooni. Tartu: Tartu Riiklik Ülikool (kordustrükid 1965, 1968, 1974).

Kleis, R. 1980: Antiikkirjanduse ajalugu: kõrgkooli õpik filoloogia erialadel. Tallinn: Valgus.

Kreeka kirjanduse antoloogia. Tallinn: Eesti Riiklik Kirjastus, 1964.

Kun, Nikolai 1959 = Kūns, Nikolajs. Sengrieķu mīti un varoņteikas. Rīga: Latvijas Valsts izdevniecība.

Kun, Nikolai 2016 = Kūns, Nikolajs. Sengrieķu mīti un varoņteikas. Rīga: Jumava.

Laizāns, M., Lāms, O. 2014: Sengrieķu īpašvārdu atveide latviešu valodā: paražas vs. paraugs lingvistikas un poētikas aspektos. In: Kalnača, A., Lokmane, I., Urbanoviča I. (toim.). Alīse Laua (1914-1994). In honorem. Rīga: LU Akadēmiskais apgāds, 98-105.

Latinu-latviešu vārdnīca. Rīga: Latvijas Valsts izdevniecība, 1954.

Mišulinas, A. V. (koost.). 1946: Senovès istorija. Kaunas: Valstybinè pedagoginès literatūros leidykla. 
Nurm, Ernst 1958. Kreeka pärisnimede edasiandmisest eesti keeles. Keele ja Kirjanduse Institundi uurimused II. Tallinn: Eesti Riiklik Kirjastus, lk 43-52.

Nurm, E., Raiet, E., Kindlam, M. 1961: «Õigekeelsuse sõnaraamatu» arvustuste puhul. Keel ja Kirjandus 9, 553-565.

Plāķis, J. 1929: Svešvārdu izruna un rakstība latviešu valodā. Izglìtības ministrijas mēnešraksts 5, 477-480.

Raiet, Erich 1966. Vabariikliku õigekeelsuse komisjoni otsuseid. Keel ja Kirjandus 3, 178.

Rooma kirjanduse antoloogia. Tallinn: Eesti Raamat, 1971.

Roos, E. 1935: Ülevaade vana-kreeka kirjandusest. Tartu: Loodus.

Rūmniece, I. 2009: Par grieķu īpašvārdiem un grēcismiem latviešu valodas vidē. Antiquitas Viva 3. Rīga: LU Akadēmiskais apgāds, 147-156.

Sengrieǩu literatūras antologija. Rīga: Zvaigzne, 1990.

Senās Romas literatūras antologija. Rīga: Zvaigzne, 1994.

Sergejevas, V. 1952: Senovès Graikijos istorija. Vilnius: Valstybinè politinès ir mokslinès literatūros leidykla.

Straubergs, K. (koost.) 1922: Grieķu lirika. Rīga: Izglītîbas ministrijas izdevums.

Straubergs, K. 1936: Romiešu literātūra. Rīga: Valters un Rapa.

Taplin, . . (toim.) trükis. Kirjandus Kreeka-Rooma maailmas. Tartu: Tartu Ülikooli Kirjastus.

Tronski, J. 1949 : Antiikkirjanduse ajalugu. Tartu: Teaduslik Kirjandus.

Tronski 1951 = Tronskis, Josifas. Antikinès literatūros istorija. Vilnius: Valstybinè politinès ir mokslinès literatūros leidykla (kordustrükid $1955,1961)$.

Tronski 1954 = Tronskis, Josifs. Antikās literaturas vēsture. Rīga: Latvijas Valsts izdevniecība.

Vecvagars, M. 2008: Sengrieķu-latviešu ìpašvārdu vārdnīca. Rīga: Filozofijas un socioloğijas institūts.

Veski, J. V. 1961: Kreeka ja ladina sõnavara omavahelisest suhtumusest eesti keeles Keel ja Kirjandus 1, 37-41.

Zieliński, T. 1926-1927: Vana-kreeka kirjandus. Tlk Linda Metslang. Tartu: Eesti Kirjanduse Selts.

\section{Bodniece, A. Kučinskienė, M.-K. Lotman. Greek proper names in ancient literature textbooks on the example of Baltic countries}

The purpose of this paper is to compare the history of rendering Greek proper names in three countries with similar fate - Latvia, Lithuania and Estonia. In order to delimit the very broad material, we have chosen as our research subject literature study books, as one of the most professional and thought-out sources, on the one hand, but also because they are works which have considerable impact and serve as significant tools for popularizing the name forms.

Keywords: Greek proper names in Latvian, Lithuanian, Estonian. 